\title{
Men's knowledge about osteoporosis and its risk factors
}

\author{
Mariola Janiszewska ${ }^{1}$, Dorota Żołnierczuk-Kieliszek ${ }^{1}$, Teresa Kulik ${ }^{1}$, Małgorzata A. Dziedzic ${ }^{1}$, \\ Agnieszka Barańska², Aneta Kryk ${ }^{3}$
}

${ }^{1}$ Chair of Public Health, Department of Health Sciences, Medical University of Lublin, Poland ${ }^{2}$ Department of Mathematics and Medical Biostatistics, Medical University of Lublin, Poland ${ }^{3}$ Graduate from Medical University of Lublin, Faculty of Health Science, Lublin, Poland

\begin{abstract}
Introduction: Until recently osteoporosis was seen mainly as a woman's problem. However, in the last ten years there has been rising awareness in society that osteoporosis constitutes an inseparable element of getting old for men as well. The aim of the research was to evaluate men's knowledge about osteoporosis and its risk factors contributing to the development of the disease.

Material and methods: The study included 205 men aged 20-60. The examined men were patients of selected healthcare centres in Lublin Voivodeship. The study was conducted between September 2014 and April 2015. The research was performed by means of the survey method, using a poll technique. Purposive sampling and an original questionnaire were used. Gathered material was subjected to descriptive and statistical analysis. The Mann-Whitney $U$ test and Kruskal-Wallis test were applied. The statistical significance level was set at $\alpha=0.05$. IBM SPSS Statistics software was used to perform the statistical analysis.

Results: The respondents' level of knowledge about osteoporosis and its risk factors can be estimated as average. The polled men showed better knowledge on osteoporosis risk factors $(M=59.78)$ than general osteoporosis knowledge $(M=53.71)$. Significant differences were found between the respondents' education and their general osteoporosis knowledge as well as between the respondents' living conditions and their knowledge about osteoporosis risk factors.

Conclusions: Because of the insufficient level of knowledge about osteoporosis and its risk factors in the male population it is advisable to launch prevention programmes aimed at men focusing on this issue.
\end{abstract}

Key words: osteoporosis, risk factors, level of knowledge, andropause, men.

\section{Introduction}

According to the definition of the National Osteoporosis Foundation (NOF) and the US National Institutes of Health $(\mathrm{NIH})$ "osteoporosis is a skeleton disease which is characterised by decreased bone strength that increases the risk of a fracture. The bone strength depends on the bone mineral density and the bone quality" [1]. Most people think that postmenopausal women constitute the majority of osteoporosis patients. However, in the last ten years there has rising awareness in society that osteoporosis constitutes an inseparable element of getting old in men as well [1].

The problem of osteoporosis in men is an unknown topic and has been described rarely. Epidemiological data tend to be questionable, and the pathogenesis of the disease is not well understood yet [2]. The results of the research on male osteoporosis show significant differences in epidemiology, the location of osteoporotic fractures, the bone structure, the pathophysiological processes leading to the development of the disease and different risk factors when compared to female osteoporosis [2]. In view of the fact that the life expectancy is getting longer and society is getting older, the number of new cases of osteoporosis is expected to rise both in Poland and worldwide. From the economic point of view it means that social expenses on osteoporosis treatment, hospitalization, rehabilitation and losses caused by osteoporosis patients' temporary or permanent inability to work will be rising constantly [3]. It has been estimated that in the USA approximately 1.5 million men over 65 suffer from osteoporosis. According to the EVOS (European Vertebral Osteoporosis Study) data, the prevalence of osteoporosis in European men is about $13 \%$, and $13.5 \%$ of men over 50 as well as $26 \%$ of men over 60 are at a high risk of osteoporotic fracture [4]. In the light of available publications one can estimate that in Poland in 2010, 465,000 men in the age group over 50 suffered from osteoporotic fractures [5].

Men suffer from osteoporotic fractures considerably less than women, but osteoporotic fractures are a sig- 
nificant cause of morbidity and mortality in elderly men [2]. The risk of osteoporotic fracture in men constitutes about one third of the fracture risk in women, but the possibility of death following the fracture is 1.6 higher in men. Vertebral column fractures occur earlier in men than in women, and in the age group 35-64 years they are diagnosed 2-3 times more often in men than in women. In patients suffering from chronic obstructive pulmonary disease, which is more prevalent in men, the fracture of each vertebra reduces total lung capacity by $10 \%$, and it makes the prognosis worse. The lifetime risk of fracture of the upper extremity of a femur in men ranges from $13 \%$ to $25 \%$. The fracture occurs later in life than in women, and the incidence rises rapidly in the eighth decade of life. The mortality from hip fracture is twice as higher in men as in women; $50 \%$ of male patients suffer from pain longer than 6 months and only $32 \%$ of male patients recover completely [6]. Men are characterised by higher peak bone density and thicker bones, which means that we can expect a smaller number of pathological fractures with the same reduction in the bone tissue mass. In men osteoporosis starts about 10 years later in life and male life expectancy is 6-8 years shorter than the female one, which is why men are diagnosed with advanced osteoporosis less frequently. On the other hand, complications resulting from osteoporosis and pathological fractures occur more frequently in elderly men than in elderly women, so the total mortality caused by osteoporosis is considerably higher in men [4]. The lack or neglect of osteoporosis treatment is a common phenomenon in many European countries. We can estimate that about $70 \%$ of male patients suffering from osteoporosis do not undergo pharmacological treatment [2].

The aetiology and symptoms of male osteoporosis are various and complicated. That is why we can find several causes of reduced bone density and pathological fractures in one patient. This situation occurs seldom in clinical practice. Classically we distinguish systemic osteoporosis and localized osteoporosis (according to location criteria). Systemic osteoporosis can be divided into primary and secondary forms. In primary osteoporosis (80\% of cases) we can distinguish involutional (senile) osteoporosis and idiopathic osteoporosis. Secondary osteoporosis can be found in 30-60\% of patients. It seems that the testosterone deficiency resulting from getting old (andropause) is the essential reason for osteoporosis pathophysiology in men, and it should be qualified as the primary reason analogically to primary postmenopausal osteoporosis in women [7] $70 \%$ of men suffering from involutional osteoporosis are diagnosed with testosterone deficiency [2].

Localized osteoporosis accompanies inflammatory processes (for instance epiphyseal osteoporosis around inflamed joints) or algoneurodystrophic processes and is limited to locations severely affected by the basic disease. In contrast, systemic osteoporosis affects the whole skeleton and results from a systemic metabolic defect which gives predominance to bone resorption processes over bone formation processes [8]. Secondary osteoporosis can be the consequence of such diseases as neoplastic tumours, hyperthyroidism, hyperparathyroidism, hypercorticism, diabetes type 1 , alimentary system diseases, chronic inflammatory diseases as well as long-term immobilisation and long-term application of medicines (glucocorticosteroids, cytostatic drugs, anticonvulsants, heparin, tetracycline) [9]. From the clinical point of view, other significant causes of osteoporosis in men include lifestyle factors, such as tobacco smoking and alcoholism [4]. This type of osteoporosis can also be caused by a lack of physical exercise. The lack of exercise can lead to a decrease of calcium resorption in the intestines. Malnutrition can be another important cause of secondary osteoporosis. Osteoporosis can be the result of calories deficiency or the deficiency of important nutrients in the diet, such as vitamins and minerals [10]. Idiopathic osteoporosis of early mature age occurs in patients aged $20-30$, almost exclusively in men $(90 \%$ of cases). The slowdown of bone formation processes is the cause of the idiopathic form of osteoporosis, which is without doubt caused by the decline in bone formation processes in bone remodelling locations, the decline in the intensity of osteoblast proliferation, and the level of vitamin D and insulin-like growth factor (ILGF-I) in the blood serum. The described form of osteoporosis differs from the other forms by very fast progress of the disease and increased excretion of calcium and hydroxyproline with urine. Then idiopathic form of osteoporosis is characterised by skeletal growth disorders, which do not follow the age norms [11]. On the other hand, the involutional form of osteoporosis is characterised by disorders in bone metabolism which make the physiological osteopenia appear earlier [12]. Calcium metabolism disorders, hypogonadism associated with aging and insufficient exercise are the main causes of involutional osteoporosis. It seems that the age-related changes in the physiology of growth factors and cytokines may be responsible for bone mass loss [7].

According to Tłustochowicz [6] the most important risk factors of male osteoporosis are as follows:

- low body mass index (BMI) $-<22$,

- low exercise,

- low calcium consumption,

- tobacco smoking,

- chronic obstructive pulmonary disease unrelated to corticosteroid treatment (50\% of patients are diagnosed with spinal vertebra fractures),

- patient's mother diagnosed with a bone fracture (it multiplies the risk by 1.5 times),

- excessive alcohol consumption,

- treatment with phenytoin causing osteomalacia,

- primary or secondary (hypogonadotropic) hypogonadism. 
Determining the level of knowledge on osteoporosis and its risk factors may be helpful in creating prevention programmes aimed at men. The opinion that osteoporosis is mainly a problem of women is prevalent in the male population. Insufficient knowledge about the basic risk factors and health behaviours makes men have double the mortality rate due to osteoporotic complications in comparison to women. In connection with the rapid growth in osteoporosis incidence in the male population it is necessary to start a campaign focused on education, forming the proper health behaviours, prevention and treatment of osteoporosis.

The aim of the study was to evaluate men's knowledge about osteoporosis and its risk factors contributing to the development of the disease.

\section{Material and methods}

The study was conducted by means of the survey method, using a poll technique. An original questionnaire consisting of 73 closed questions was used as a research tool. The questions of the questionnaire were sorted into five parts concerning socio-demographic data, preferred form of physical exercise, self-estimation of health state, the respondents' health behaviours and the general knowledge on osteoporosis as well as the knowledge about osteoporosis risk factors.

The gathered material was subjected to descriptive and statistical analysis. The values of quantitative parameters were presented as the arithmetic mean and standard deviation, whereas the qualitative parameters were presented as frequencies and percentages. The examined men's general knowledge on osteoporosis and their knowledge on osteoporosis risk factors were treated as dependent variables, whereas respondents' education, permanent place of residence, living conditions and self-estimation of health status were treated as independent variables.

The Mann-Whitney $U$ test and Kruskal-Wallis test were applied respectively to test for statistical differences between two or more groups in the case of variables whose distribution was significantly different from normal. The statistical significance level was set at $\alpha=$ 0.05. IBM SPSS Statistics software was used to perform the statistical analysis.

The study was conducted between September 2014 and April 2015. The study included 205 men aged 20-60. The examined men were patients of selected healthcare centres in Lublin Voivodeship (Independent Public Clinical Hospital No. 4 in Lublin, the Independent Healthcare Centre in Bychawa, the Rural Healthcare Centre in Stara Wieś, the Communal Health Care Centre in Wysokie and the Communal Health Care Centre in Krzczonów). Purposive sampling was used. The majority of the subjects were city dwellers (63.4\%), whereas rural inhabitants constituted $36.6 \%$ of the polled group.
Over half of the respondents (53.7\%) had secondary education, every third man (34.6\%) had higher education and $11.7 \%$ of the respondents had vocational education. Single men constituted the vast majority of the respondents (82.4\%). $17.6 \%$ of the examined men were married or currently in an informal relationship. Half of the respondents (50.2\%) evaluated their living conditions as good. Over one fourth of the subjects (26.8\%) described his living conditions as very good, whereas every fifth (19.5\%) respondent described his living conditions as average. Bad living conditions were reported by $3.4 \%$ of the polled men. Describing the health behaviours of the polled men in connection to osteoporosis, over half (53.7\%) of the respondents reported undertaking regular exercise. About one third of the men (29.8\%) reported tobacco smoking and $24 \%$ of them drank more than 2-3 cups of strong coffee or tea per day. Only $23.9 \%$ of the subjects reported having a diet rich in calcium every day.

\section{Results}

The analysis of respondents' answers to each question of the questionnaire allowed us to determine the respondents' general level of knowledge on osteoporosis and their level of knowledge on osteoporosis risk factors.

The general osteoporosis knowledge was evaluated by the use of 8 questions which could be answered correctly (1 point scored) or incorrectly (0 points scored) and by the use of one multiple answer question in which the subjects were presented with 11 symptoms of osteoporosis. The respondent scored 1 point for this particular question when he had indicated at least 5 correct osteoporosis symptoms. So the maximum score for each respondent was 9. Then the number of every respondent's scored points was divided by the maximum possible score. The achieved percentages of maximum available score were presented in further analysis.

Then the respondents' knowledge on osteoporosis risk factors was assessed by the use of 18 questions of the questionnaire, to which the respondent could give the correct answer and score 1 point or give a wrong answer (0 points). So the maximum score for each respondent was 18 . Then the number of every respond-

Tab. I. General osteoporosis knowledge and the knowledge on osteoporosis risk factor indexes

\begin{tabular}{lccccc}
\hline & $\boldsymbol{N}$ & Min & Max & M & SD \\
\hline $\begin{array}{l}\text { Level of general } \\
\begin{array}{l}\text { knowledge on } \\
\text { osteoporosis }\end{array}\end{array}$ & 205 & 11.11 & 100.00 & 53.71 & 18.18 \\
\hline $\begin{array}{l}\text { Level of knowledge } \\
\begin{array}{l}\text { on osteoporosis risk } \\
\text { factors }\end{array}\end{array}$ & 205 & 22.22 & 88.89 & 59.78 & 13.59 \\
\hline
\end{tabular}


ent's scored points was divided by the maximum possible score. The achieved percentages of the maximum available score were presented in Table I.

As we can see in this table the respondents' scores in general osteoporosis knowledge test varied from $11.1 \%$ to $100 \%$ of the maximum available score. The average score was $59.8 \%$ points. On the other hand the examined gained from $22.25 \%$ to $88.9 \%$ of maximum available score in the test on osteoporosis risk factors. The average score was $59.8 \%$ points. So the polled men showed better knowledge on osteoporosis risk factors $(M=59.78)$ than general osteoporosis knowledge $(M=53.71)$.

The examined men were asked to estimate their own level of knowledge on osteoporosis. Nearly half of them $(47.3 \%)$ determined their level of knowledge as average, $36.6 \%$ of respondents claimed that they had a low level of knowledge on osteoporosis, $13.2 \%$ of the respondents estimated their level of knowledge as high and $2.9 \%$ as very high (Fig. 1 ).

The secretion of testosterone is an important element to achieve and sustain the maximum bone mass in adolescent boys and men. Over half of the respondents (58.6\%) gave the correct answer to the question 'What is the main cause of bone mass loss in men?', that is the declining level of testosterone and calciumphosphate metabolism disorders. The remaining men gave the incorrect answer to the question; that is, $26.8 \%$ indicated inadequate diet, $7.8 \%$ increased exercise and $6.8 \%$ claimed that fatigue was the main cause of bone mass loss in men (Fig. 2).

The polled men were asked the question about the consequences of osteoporotic fractures. Slightly over half of the respondents (51.7\%) were aware of the fact that permanent physical disability can be the consequence of bone fractures caused by osteoporosis. Over one fourth of those examined indicated inflammation of bones and joints as a consequence, $7.3 \%$ indicated muscle atrophy and $15.1 \%$ of the respondents did not know how to answer the question. The above-mentioned data are depicted in Fig. 3.

The next question of the questionnaire referred to the osteoporosis risk factors which can significantly increase the chances of developing the disease. One should remember that when diagnosing osteoporosis the analysis of existing risk factors plays an important role apart from physical examination of the patient and bone density measurement. The analysis of the obtained results proved that the majority of the respondents $(70.2 \%)$ were aware that genetic factors can influence the development of osteoporosis in men. An incorrect answer to the question was given by $29.8 \%$ of those examined. The respondents were asked the question: 'Does a petite body build decrease the possibility of developing osteoporosis?' Almost two thirds of the respondents (60.5\%) stated the correct opinion that a petite body built does not decrease the chances of developing osteoporosis because it is one of the risk factors of male osteoporosis. An incorrect answer was given by the remaining $39.5 \%$ of the polled group. Over half of the respondents (56.6\%) claimed correctly that tobacco smoking constitutes a significant risk factor

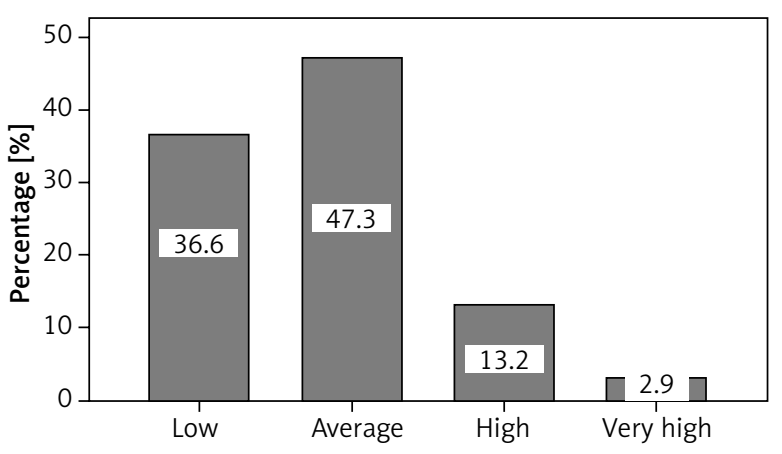

How do you estimate your level of knowledge on osteoporosis?

Fig. 1. Self-estimation of respondents' knowledge on osteoporosis

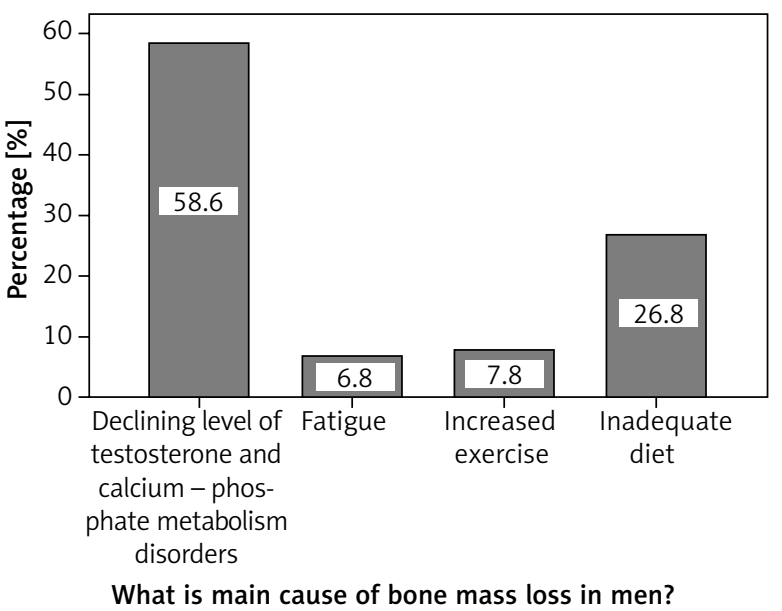

Fig. 2. Main cause of bone mass loss in men according to the respondents

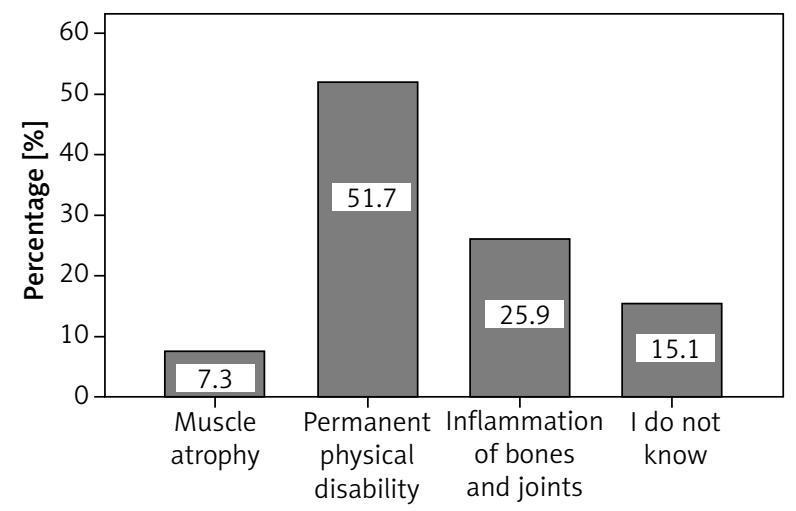

What are the consequences of osteoporotic fractures according to you?

Fig. 3. Consequences of osteoporosis of bone fractures according to the respondents 
of osteoporosis. The vast majority of the polled group stated that alcohol overuse increased the probability of falling ill with osteoporosis. Similarly, $71.7 \%$ of the examined men were aware that drinking a huge amount of strong coffee and tea could have a negative influence on bone condition, causing the loss of important minerals and a decrease in mineral bone density. Physical exercise is essential in normal bone development and therefore is an important element in osteoporosis prevention. The vast majority of the respondents (82\%) gave the correct answer to the question 'Does a lot of exercise increase the risk of developing osteoporosis?', that is the answer 'no'. Also over two thirds of the polled group $(69.8 \%)$ were right in stating that inadequate sunlight exposure can increase the risk of osteoporosis in men. Vitamin D synthesis takes place in a human skin exposed to UVB radiation. We can be worried that less than half of the respondents (44.4\%) were aware of the important role of vitamin D in osteoporosis prevention. Nearly half of the respondents (47.8\%) perceived the beneficial impact of sufficient calcium supply on the condition of the bones.

The statistical analysis of the obtained study results showed significant differences between the respondents' education and general knowledge about osteoporosis $(p<0.007)$. More highly educated men showed a significantly higher level of general osteoporosis knowledge $(M=57.43)$ than men with secondary education $(M=50.1)$. What is interesting, the highest level of general osteoporosis knowledge was shown by men with vocational education ( $M=59.7 \%)$. However, no statistically significant differences were found between the respondents' education and their knowledge about osteoporosis risk factors (Table II).

Statistically significant differences were observed between the respondents' living conditions and their level of knowledge on osteoporosis risk factors $(p=0.01)$. Men from very good living conditions had significantly better knowledge $(M=63.84)$ than men from good living conditions $(M=57.28)$. No statistically significant differences were found between the respondents' living conditions and their general knowledge about osteoporosis. The results are shown in Table III.

There were no statistically significant differences between the respondents' permanent place of living and their general knowledge on osteoporosis and their knowledge on osteoporosis risk factors.

No statistically significant differences were revealed between single men and men in formal or informal relationships and the respondents' general knowledge about osteoporosis $(p=0.21)$ and their knowledge on osteoporosis risk factors $(p=0.58)$. It is worth noting that the average index of knowledge in men in relationships was distinctly higher $(M=57.72 \%)$ than the average index in single men ( $M=25.86 \%)$.

After conducting the analysis between the self-evaluation of the respondents' own knowledge on osteoporosis and the real level of knowledge, it was found that there were statistically significant differences between the self-evaluation of osteoporosis knowledge and both the level of general osteoporosis knowledge $(p<0.001)$ and the knowledge about osteoporosis risk factors

Tab. II. Influence of education on the level of general knowledge on osteoporosis and on the level of knowledge about osteoporosis risk factors

\begin{tabular}{|c|c|c|c|c|c|}
\hline \multirow{2}{*}{ Education } & & \multicolumn{2}{|c|}{ Level of general knowledge on osteoporosis } & \multicolumn{2}{|c|}{ Level of knowledge on osteoporosis risk factors } \\
\hline & & $M$ & SD & M & SD \\
\hline Vocational (1) & & 59.26 & 17.23 & 55.56 & 12.69 \\
\hline Secondary (2) & & 50.10 & 17.47 & 59.29 & 13.42 \\
\hline Higher (3) & & 57.43 & 18.59 & 61.97 & 13.92 \\
\hline \multirow[t]{2}{*}{ Kruskal-Wallis test } & $\mathrm{H}$ & 9.959 & & 4.196 & \\
\hline & $p$ & 0.007 & & 0.123 & \\
\hline \multicolumn{2}{|c|}{ Statistically significant differences } & $2-3$ & & & \\
\hline
\end{tabular}

Tab. III. Influence of social and living conditions on the level of general knowledge on osteoporosis and the level of knowledge on osteoporosis risk factors.

\begin{tabular}{|c|c|c|c|c|c|}
\hline \multirow{2}{*}{$\begin{array}{l}\text { Social and living } \\
\text { conditions }\end{array}$} & & \multicolumn{2}{|c|}{ Level of general knowledge on osteoporosis } & \multicolumn{2}{|c|}{ Level of knowledge on osteoporosis risk factors } \\
\hline & & $M$ & SD & $M$ & SD \\
\hline Very good (1) & & 56.97 & 20.40 & 63.84 & 12.37 \\
\hline Good (2) & & 52.64 & 17.81 & 57.28 & 14.00 \\
\hline Average and bad (3) & & 52.25 & 16.04 & 60.52 & 13.07 \\
\hline \multirow[t]{2}{*}{ Kruskal-Wallis test } & $\mathrm{H}$ & 3.660 & & 9.301 & \\
\hline & $p$ & 0.160 & & 0.010 & \\
\hline \multicolumn{3}{|c|}{ Statistically significant differences } & & $1-2$ & \\
\hline
\end{tabular}


$(p<0.001)$ It was found that men who estimated their level of knowledge as high or very high indeed gained a higher score in the osteoporosis knowledge test $(M=$ 62.26) than men estimating their level of knowledge as low $(M=48.29)$. Similarly, respondents who evaluated their level of knowledge on osteoporosis risk factors as high or very high were characterised by better test scores $(M=68.52)$ than respondents evaluating their osteoporosis knowledge as average $(M=59.79)$ or low $(M=55.93)$. The above data are presented in Table IV.

\section{Discussion}

Osteoporosis was recognized by the World Health Organization as a disease of affluence and an epidemic of the $21^{\text {st }}$ century [13].

The implementation of osteoporosis prevention rules means promoting health behaviours making the quality of human bones better, the identification of persons extremely prone to developing the disease and diagnosing the osteoporosis as well as starting the treatment in the early stage of the disease before fractures occur [14].

Our results suggest that the respondents' general knowledge on osteoporosis can be estimated as average $(M=53.71)$. Similar results were obtained by Gaines and co-workers [15], who researched men's knowledge on osteoporosis in the United States. According to their results, only $39 \%$ of respondents were able to give correct answers to questions concerning the disease. A similar observation was reported by Chinese researchers, who rated the level of knowledge about osteoporosis among elderly Chinese man as 32$36 \%$ [16]. It is worth drawing attention to the studies of Elayeh et al. [17], according to whom only $26.5 \%$ of Jordanian respondents evaluated their knowledge on osteoporosis as sufficient, and after participating in the training on osteoporosis the percentage rose to $38.6 \%$.

Learning about the risk factors of the disease comprises an important element of education on osteopo- rosis. Our data suggest that the polled men were characterized by an average knowledge on osteoporosis risk factors $(M=59.8)$. The results obtained by Szczygielska-Majewska and Papis [18], who researched 120 patients of the Orthopaedic Ward of the Central Clinical Hospital of the Ministry of National Defence in Warsaw, showed a low level of the patients' knowledge on osteoporosis risk factors. $54.4 \%$ of the patients were incapable of indicating the osteoporosis risk factors correctly. Similarly, Martin et al. [19], researching a group of schoolgirls from a public school in Michigan, reported the insufficient level of the girls' knowledge about the risk factors, the sources of calcium in the diet, and the role of physical exercise in osteoporosis prevention. Moreover, studies conducted in Scotland demonstrated insufficient level of women's knowledge on osteoporosis risk factors in $31.8 \%$ of the polled women, while $19.3 \%$ of the respondents did not know how to prevent osteoporosis [20].

The results of our study showed that $95.1 \%$ of the respondents gave the correct answer to the question about the essence of osteoporosis. On account of the lack of appropriate research among men, it is worth referring to the problem amongst women. Malara et al. [21], who conducted a study on women from Dąbrowa Górnicza (a city in southern Poland) [21], found that $38.3 \%$ of the examined women heard about osteoporosis but were not able to give the correct definition of the disease, $29 \%$ of women managed to formulate the correct definition, whereas $32.7 \%$ had no knowledge about the disease.

One of the most important aspects of osteoporosis prevention is the appropriate amount of exercise. Our results suggest that $82 \%$ of respondents appreciated the role of physical exercise in improving bone strength. However, according to the results obtained by Lewczuk and Białoszewski, who researched the patients of Mokotów Osteoporosis Centre in Warsaw [22], in the opinion of $68.5 \%$ of the respondents osteoporosis brought about a decrease in the patients' everyday

Tab. IV. Level of general knowledge on osteoporosis and knowledge of osteoporosis risk factors and the self-estimation of osteoporosis knowledge

\begin{tabular}{lcccc}
\hline & \multicolumn{3}{c}{ How do you estimate your level of knowledge on osteoporosis? } \\
\hline & Level of general knowledge on osteoporosis & Level of knowledge on osteoporosis risk factors \\
\hline Low (1) & M & SD & M & 55.93 \\
\hline Average (2) & 48.29 & 16.99 & 14.88 & 11.72 \\
\hline High / Very high (3) & 54.98 & 16.77 & 68.52 & 11.84 \\
\hline \multirow{2}{*}{\begin{tabular}{l} 
Kruskal-Wallis test \\
\cline { 2 - 5 }
\end{tabular}} & $\mathrm{H}$ & 15.510 & 21.14 & 19.434 \\
\hline $\begin{array}{l}\text { Statistically significant } \\
\text { differences }\end{array}$ & 0.000 & & 0.000 \\
\hline
\end{tabular}


physical exercise level. According to Podbielska et al. [23], the level of knowledge about the role of exercise among women over 50 years of age was inadequate in $7 \%$ of the women, sufficient and good in $15 \%$ and very good in $63 \%$ of the respondents. Gemalmaz and Oge [24], who conducted their study in Turkish women aged 40-70 from western Anatolia, reported that only 18\% of the polled women indicated lack of exercise as an osteoporosis risk factor. In contrast, according to the results obtained by Edmond et al. [25], as many as $80.3 \%$ of the examined students saw the profits from regular physical exercises for osteoporosis prevention.

Tobacco smoking, alcohol overuse and regular drinking of strong coffee and tea are recognized as important osteoporosis risk factors. In our study the respondents indicated drinking huge amounts of strong coffee and tea (71.7\%), alcohol overuse (71.25\%) and tobacco smoking (56.6\%) as osteoporosis risk factors. Slightly different results were presented by Shawa et al. [26], who conducted research on 130 male patients of Saint Joseph Hospital in Denver. Only $38 \%$ of the hospital patients indicated tobacco smoking as an osteoporosis risk factor, and only $20 \%$ of them supported the opinion that caffeine overconsumption was a significant osteoporosis risk factor. Over one third of those examined considered alcohol overuse as another osteoporosis risk factor. Studies by Ochota and Mroczek [27] showed an inadequate level of knowledge about the harmful effect of stimulants both in the group of physiotherapy students and in women over 40 years of age. Only $24 \%$ of the students and $30.6 \%$ of women over 40 years of age were aware of the harmful effect of stimulants on bone condition. On the other hand, the results of the research performed on 300 Polish women aged 45-65 obtained by Janiszewska et al. [28] showed that $41.7 \%$ of the examined women had sufficient knowledge about tobacco smoking as an osteoporosis risk factor. Alarming conclusions were presented by Wahba et al. [29]. They investigated the osteoporosis knowledge of 494 pupils aged 16-24 from Cairo. According to their results, only $6 \%$ of the pupils were aware of the fact that tobacco smoking was a risk factor of osteoporosis development.

The present study results showed statistically significant differences between the respondents' education and their general knowledge on osteoporosis. Better educated men showed a significantly higher level of general osteoporosis knowledge than men with secondary education. On the other hand, the highest level of general osteoporosis knowledge was shown by men with vocational education. The studies of Chen et al. [30] on nurses specialized in public health work in Taiwan revealed that nurses without higher education, who took part in training on osteoporosis, showed a higher level of osteoporosis knowledge than nurses with higher education not attending the training.

\section{Conclusions}

1. The respondents' level of knowledge about osteoporosis and its risk factors can be estimated as average. The polled men showed better knowledge on osteoporosis risk factors $(M=59.78)$ than general osteoporosis knowledge $(M=53.71)$.

2. Over half of the respondents demonstrated knowledge about the reasons of bone mass loss and the consequences of osteoporotic fractures.

3. Most of the polled men were able to identify the risk factors of osteoporosis such as low physical exercise, drinking too much strong coffee or tea, alcohol overuse or genetic factors. We can be worried that less than half of the examined subjects were aware of the important role of a sufficient supply of calcium and vitamin $\mathrm{D}$ in osteoporosis prevention.

4. No significant differences were observed in the respondents' osteoporosis knowledge between urban and rural dwellers or between single men and men in formal or informal relationships. Significant differences were found between the respondents' education and their general osteoporosis knowledge as well as between the respondents' living conditions and their knowledge about osteoporosis risk factors.

5. The self-estimation of the respondents' osteoporosis knowledge reflected their actual knowledge.

6. Because of the insufficient level of knowledge about osteoporosis and its risk factors in the male population it is advisable to launch prevention programmes aimed at men focusing on this issue.

\section{Disclosure}

Authors report no conflict of interest.

\section{References}

1. Głuszko P. Osteoporoza - spojrzenie w przeszłość. Reumatologia 2011; 49: 372-377.

2. Głuszko P. Osteoporoza u mężczyzn - nowe możliwości leczenia; http:// www.ereumatologia.pl/Osteoporoza-u-mezczyzn-nowe-mozliwoscileczenia,13515.html (access 12.06.2016).

3. Malec S, Zaręba I, Rółkowski K, et al. Osteoporoza - problem społeczny i ekonomiczny. Pol Prz Nauk Zdr 2014; 39: 167-171.

4. Rabijewski M. Osteoporoza u mężczyzn. Prz Urol 2006; 35: 43-45.

5. Czerwiński E, Boczoń K, Kumorek A. Epidemiologia złamań osteoporotycznych. Post Nauk Med 2012; 3: 206-212.

6. Tłustochowicz W. Ostoporoza i osteomalacja. In: Reumatologia kliniczna. Zimmermann-Górska I (ed.). Wydawnictwo Lekarskie PZWL, Warszawa 2008.

7. Rabijewski M. Osteoporoza u mężczyzn - etiologia i czynniki ryzyka. Prz Urol 2004; 23: 21-25.

8. Badurski J.E. Osteoporoza w chorobach reumatycznych. In: Reumatologia. Mackiewicz S, Zimmermann-Górska I (eds.). Wydawnictwo Lekarskie PZWL, Warszawa 1995.

9. Chwalińska-Sadowska H. Osteoporoza - przyczyny, diagnostyka, profilaktyka i leczenie. In: Reumatologia w praktyce lekarza rodzinnego. Zimmermann-Górska I (ed.). Wydawnictwo Lekarskie PZWL, Warszawa 1998.

10. Colbin A. Osteoporoza. Jak leczyć dietą? Książka i wiedza, Warszawa 2000. 
11. Spodaryk K. Patologia narządu ruchu. Wydawnictwo Lekarskie PZWL, Warszawa 2002.

12. Olejniczak T, Opala T, Woźniak J, et al. Osteoporoza - epidemiologia, patogeneza, diagnostyka i leczenie. Przew Lek 2000; 9: 39-47.

13. Janiszewska $M$, Kulik T, Dziedzic $M$, et al. Osteoporoza jako problem społeczny - patogeneza, objawy i czynniki ryzyka osteoporozy postmenopauzalnej. Probl Hig Epidemiol 2015; 96: 106-114.

14. Buczkowski K, Chlabicz S, Horst-Sikorska W. Osteoporoza. Postępowanie profilaktyczne, diagnostyczne i lecznicze. Wytyczne dla lekarzy podstawowej opieki medycznej. Forum Med Rodz 2012; 6: 153-160.

15. Gaines JM, Marks KA, Caudill J, et al. Older Men's Knowledge of Osteoporosis and the Prevalence of Risk Factors. J Clin Densitom 2010; 13: 204-209.

16. Yin-King Lee L. Osteoporosis in older Chinese men: knowledge and health beliefs. J Clin Nurs 2006; 1: 5353-5355.

17. Elayeh E, Akour A, Yousef A. Osteoporosis Amongst Jordanians: Effect of Pharmacist Directed Brochure Education on People's Knowledge. Trop J Pharm Res 2014; 13/12: 2101-2108.

18. Szczygielska-Majewska M, Papis E. Styl życia a osteoporoza. Ann UMCS Sect D 2003; 58: 243-246.

19. Martin J, Coviak C, Gendler P, et al. Female Adolescents' Knowledge of Bone Health Promotion Behaviors and Osteoporosis Risk Factors. Orthop Nurs 2004; 4: 235-244.

20. Spencer S. Lack of knowledge of osteoporosis: a multi-centre, observational study. Scott Med J 2007; 52: 13-16.

21. Malara M, Kowalska I, Klar A. Poziom wiedzy kobiet na temat osteoporozy. Mag Pielęg Położ 2014; 1/2: 28.

22. Lewczuk E, Białoszewski D. Poziom aktywności fizycznej chorych na osteoporozę a upadki i ich profilaktyka. Ortop Traumatol Rehab 2006; 4/6: 412-421.

23. Podbielska M, Sokołowski K, Sokołowska M. Ocena poziomu wiedzy na temat osteoporozy i stosowanej profilaktyki wśród kobiet po 50 roku życia. Zesz Nauk WSSP 2013; 17: 87-96.

24. Gemalmaz A, Oge A. Knowledge and awareness about osteoporosis and its related factors among rural Turkish women. Clin Rheumatol 2008; 27: 723-728.

25. Edmond E, Turner L, Usdan S. Osteoporosis knowledge, beliefs, and calcium intake of college students: Utilization of the health belief model. Open J Prev Med 2012; 2: 27-34.

26. Shawa H, Favela E, Diaz J. Knowledge of osteoporosis among men in the primary care setting. South Med J 2011; 8: 584-588.

27. Ochota A, Mroczek M. Porównanie wiedzy kobiet po 40 roku życia i studentek fizjoterapii na temat osteoporozy. Zamojskie Studia i Materiały 2012; 1/35: 127-130.

28. Janiszewska M, Kulik T, Dziedzic M, et al. Chosen risk factors for osteoporosis and the level of knowledge about the disease in peri- and postmenopausal women. Prz Menopauz 2015; 14: 27-34.

29. Wahba S, El-Shaheed A, Tawheed M. Osteoporosis knowledge, beliefs, and behaviors among Egyption female students. Journal of the Arab Society for Medical Research 2010; 2: 173-180.

30. Chen I, Yu S, Wang T, Cheng S, et al. Knowledge about osteoporosis and its related factors among public health nurses in Taiwan. Osteoporosis Int 2005; 16: 2142-2148. 